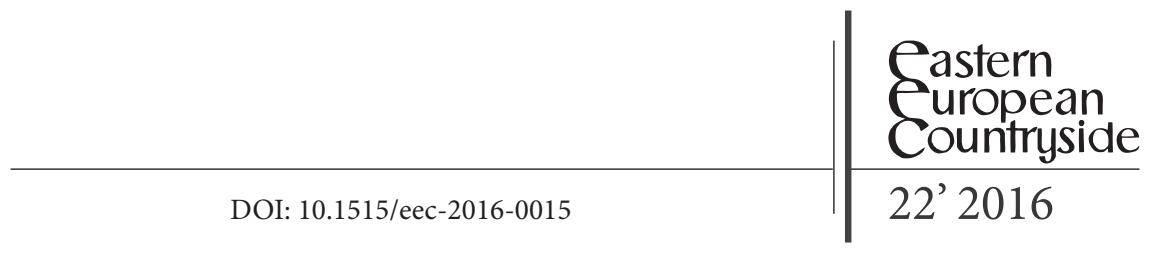

Hanna Podedworna

Warsaw University of Life Sciences, Poland

\title{
Fortieth Anniversary of IV World Congress of Rural Sociology in Toruń ${ }^{1}$
}

The XXVII European Society for Rural Sociology Congress will be held in Poland next year (Cracow, 24 to 27 July 2017). However, it will not be the first time Polish rural sociologists have hosted such a spectacular event. Exactly forty years ago, in 1976 (and in a completely different political system, and from behind the "Iron Curtain") they hosted the IV World Congress of Rural Sociology (Toruń, 9 to 13 August, 1976), as well as the IX European Society for Rural Sociology Congress. Therefore, the significance of the event was twofold.

The initiative to organise the Congress in Poland was taken by professor Bogusław Gałęski, the Head of the Rural Sociology Department at the Institute of Philosophy and Sociology of the Polish Academy of Sciences

1 This text was written by professor Hanna Podedworna from the Department of Sociology at Warsaw University of Life Sciences, who is one of the most prominent Polish rural sociologists. In 1976, as a doctoral student at the Institute of Sociology at the University of Warsaw, she worked in the organising office for the IV. World Congress of Rural Sociology, which gave her the chance to see the preparatory work and the event itself behind the scenes. On the $40^{\text {th }}$ anniversary of the Congress, editors of EEC asked professor Podedworna to share some of her memories, concerning not only substantive matters but, most of all, those that cannot be found in the Congress proceedings. 
(IFiS PAN). Using his contacts in the American scientific community and participating in international congresses, he attracted enthusiasm and support from American researchers, including Prof. Glenn V. Fuguitt from Madison University and Alvin Bertrand from Baton Rouge. Hence, the III World Congress of Rural Sociology ${ }^{2}$ was held between 22 to 27 August 1972. The organisation of the Congress and its programme were managed by The Committee for International Cooperation in Rural Sociology, which had been active before in the creation of the International Rural Sociological Association (IRSA) ${ }^{3}$. At that time, IRSA was in the organisation stage, which ended during the Congress with the first general meeting of its members. The idea of creation of IRSA was first submitted at the conference in Rome in 1973. The committee appointed the Programme Committee as responsible for the substantive side of the Congress: the main theme, plenary session speeches, topics of thematic sections etc.

On behalf of the Programme Committee, and with its full approval, the Local Organising Committee was created to organise the Congress in Poland. It was composed of the members of the Section of Rural Sociology and Agriculture of Polish Sociological Association. Members of the Committee (in an alphabetical order) were: Bogusław Gałęski - the chairman; Eugenia Jagiełło-Łysiowa, Mikołaj Kozakiewicz, Krzysztof Kwaśniewski, Zbigniew Kwieciński, Bronisław Sałuda, Lili Maria Szwengrub - the secretary; Jan Turowski - 1st vice-chairman, Barbara Weber and Zbigniew T. Wierzbicki - 2nd vice-chairman, Zbigniew A. Żochowski. It is worth noting that the chairman, the vice-chairman (Z. T. Wierzbicki) and the secretary of the Local Organizing Committee were all employees of the Rural Sociology

2 Previously, two took place in Dijon, France (16-20 August 1964) and in Enschede, Netherlands (5-10 August 1968).

3 The IRSA - created in 1975 by European, American and South American Societies of Rural Sociology to represent rural sociologists from all around the world was still being institutionalised at that time. Only after the Congress was the statute adopted, which helped in organising the V World Congress of Rural Sociology in Mexico City, 7 to 12 August 1980. During the Congress, the first general meeting of the members of the International Rural Sociological Association took place. Its board was elected in 1975 and in the postal survey,.Glenn V. Fuguitt (USA) was appointed a chairman, Bogusław Gałęski (Poland) 1st vice-chairman and Jose Pastore (Brasil) - 2nd vice-chairman. 
Department in the IFiS PAN at the time. As reported by Lili M. Szwengrub ${ }^{4}$, the Local Organising Committee was made up of people of good will, with no institutional nor financial background and it would not be able to rise to the challenge on its own. This is why a 41-person Honorary Committee was created under the leadership of the Minister of Agriculture of the time, Kazimierz Barcikowski. The Committee was composed of academics, local and national government representatives as well as agricultural institutions. The burden of preparatory work fell on the shoulders of Dr. Szwengrub.

The aforementioned Programme Committee, acting under the leadership of Prof. Glenn V. Fuguitt, designated the main topic of the Congress to be "The Integrated Development of Human and Natural Resources. The Contribution of Rural Sociology". This had to be approved not only by the Faculty of Social Sciences of the Polish Academy of Sciences but, most importantly, by the Central Committee of the Polish United Workers' Party. The initiative was supported by the General Board of Polish Sociological Association, the directors at IFiS PAN, the Institute of Rural and Agricultural Development (IRWiR PAN) and the Institute of Agricultural Economics as well as the director of the Agricultural Education Department at the Ministry of Agriculture, Marian Brzóska. Owing to its odd, and above all, politically indifferent overtone $e^{5}$, it did not arouse any opposition. However, final approval was preceded by many meetings and discussions with the so-called decision makers, who wanted the content of the conference to be explained to them - mostly by Prof. Gałęski. As I remember, he obliged, but with no great enthusiasm.

Another important issue over which the Local Organising Committee had to negotiate with the communist authorities was the location of the Congress. As a result of the endeavours of organisers, the authorities agreed

4 L.M. Szwengrub, IV Światowy Kongres Socjologii Wsi, 9-13.VIII 1976, Toruń in: "Rural Sociology Annuals," ("Roczniki Socjologii Wsi”) V.XIV, 1976, pp. 259-268.

5 The term "integrated development" appeared in Polish sociology for the first time back then and its Polish translations aroused much controversy. The first version, proposed in the initial Polish Congress programme, was "zintegrowany rozwój", although after many discussions, it was decided that "kompleksowy rozwój" (not used in this context contemporarily) captures the heart of the matter better. The main theme of the Congress referred directly to a growing interest in the natural environment and the concept of sustainable development, which in the 1970s, was seen as an interesting and innovative theoretical proposition in rural sociology. 
on Nicolaus Copernicus University (UMK) in Torun, in spite of (or maybe because of) the fact that there was no sociological faculty ${ }^{6}$ at that time. In my opinion, the choice of the city and Copernicus University was made based on two factors, all of which I will discuss in an order that does not necessarily reflect their actual importance ${ }^{7}$.

The University of Nicolaus Copernicus, on the 500th anniversary of Copernicus' birth (1473), had a new scenically-located campus built in the woods, with a large canteen, a modern library and an assembly hall, where plenary sessions with cabin interpretations could be held. My assumption was confirmed by Prof. Zbigniew Kwieciński ${ }^{8}$ (a member of Local Organizing Committee), who pointed out that Torun was chosen by Prof. Gałęski and Prof. Wierzbicki owing to the existence of the University's new campus and the presence of two rural sociology institutions: the Department in the Faculty of Humanities at Nicolaus Copernicus' University (headed by a member of the Local Organizing Committee, Włodzimierz Wincławski) and the Research Facility of IRWiR PAN (headed by Zbigniew Kwieciński). The heads of both institutions were well-known and appreciated by Prof. Gałęski and Prof. Wierzbicki, important figures in the world of rural sociology. They were both appointed secretaries of the organising committee, although they were later deprived of their functions as a result of their refusal to make the records of the Congress' participants accessible to the Security Services .

The second reason for choosing Toruń, and equally important in my opinion, were the objections of the organisers against locating such a big

6 The Department of Sociology was created at Nicolaus Copernicus University in 1946, but was closed in 1950. It shared the fate of academic sociology, which was removed from Polish universities as a result of political establishments made by communist authorities. It was re-established in 1976 (it's hard not to see the coincidence of dates), but sociology could be studied in Torun only after the transformation processes of 1989. W. Wincławski, Dzieje socjologii w Toruniu do końca wieku XX, in: Cztery dekady socjologii na Uniwersytecie Mikołaja Kopernika. Socjologia wsi krajów Europy Środkowej, ed. A. Kaleta, Toruń 2012, pp.34-50.

7 I give my opinion about the conditions underlying this decision as an employee of the organisational office in Warsaw. I did not take part in the high-level discussions, neither in Warsaw nor in Torun and I was not informed about any of them.

8 As per my e-mail correspondence with Prof. Zbigniew Kwieciński Ph. D., with whom I discussed some of the organizational issues.

9 I did not know about this last issue. When I took the job in the organizational office (December 1975), Dr. Szwengrub was the secretary. 
event in Warsaw. The organisers of the Congress were afraid that the authorities would not grant permission for so many people from all around the world to come to the capital city of Poland and stay there for several days. As a consequence, from the very beginning of the negotiations, it was suggested that the Congress should be held outside Warsaw. Torun seemed to meet all the requirements due to its rich history, beauty, attractive situation and convenient rail connection to Warsaw, as well as its plethora of hotels, which was otherwise a great problem for the majority of Polish cities and large academic centres at that time. Support given by the Copernicus University and the three voivodships' authorities (Toruń, Bydgoszcz and Włocławek) was also of great importance. Both Lili M. Szwengrub and Mikołaj Kozakiewicz emphasised their positive attitude towards the event in their reports ${ }^{10}$.

As it turned out, the choice of Torun and Nicolaus Copernicus University as the location of the event was ultimately a great success for one more reason which is today historical, but then politically important, arising in June of 1976.

Nearly two months before the start of the Congress economic issues (lack of goods in stores and lengthy queues for sugar, which became rationed in July, 1976) triggered a series of protests against the Communist authorities in Poland.

As it turned out, the choice of Torun and Nicolaus Copernicus University was a great success for one more reason - today historical, but then politically important - that arose in June of 1976, two months before the start of the Congress. Economic issues (lack of goods in stores andlengthy queues for sugar, which became rationed in July, 1976) triggered a series of protests against the Communist authorities. Protests, and most of all the resulting repercussions, resulted in the establishment of the Workers' Defence Committee - an important manifestation of civil society that played an enormous role in the Solidarity Revolution (1980-1981). The Committee was independent from the authorities, who fought fiercely against it. The Congress' organisers were afraid that political tensions might make the authorities withdraw their permit for organising such a big, international event, so ensuring that people

10 L.M. Szwengrub IV Światowy Kongres Socjologii Wsi, "Rural Sociology Annuals" (“Roczniki Socjologii Wsi”) V.XIV/1976, pp. 259-261; M. Kozakiewicz, IV Światowy Kongres Socjologii Wsi w Toruniu (9-13 VIII 1976) "Village and Agriculture" ("Wieś i Rolnictwo") 1/1977, pp. 175-179. 
would not see the social life behind the so-called "Iron Curtain". Thankfully, these concerns turned out to be unfounded. The prior decision was sustained and the IV World Congress of Rural Sociology was held as planned.

To promote the Congress and enable the researchers and scientists from the Soviet Bloc to participate, a two-day conference was held in the fall of 1975 in Jabłonna near Warsaw, involving representatives of the Academies of Sciences from the Soviet Bloc. Its aim was to decide upon the strategy of their participation in the Congress and its proceedings. Such plans were handed over to the authorities of their native Academies of Sciences as directives regulating the nature of their employees' participation in the Congress. It should be recalled that at the time, such participation would not be possible without the relevant academic authorities' official approval of both the topic of the Congress and submitted papers. In this context, of particular significance was the fact that Prof. Tatyana Zaslavskaya from the Academy of Sciences of the USSR in Novosibirsk, was appointed chairwoman of one of the thematic groups (no. 8); on the one hand, this indicated an appreciation of her scientific output, while on the other hand it emphasised the meaning of rural sociology of the Soviet bloc and its input into world sociology. Let me stress that among the chairmen of the 21 thematic groups, Prof. Zaslavskaya was the only one to represent socialist science, even though the whole Soviet delegation numbered over 30 members. I also remember Prof. Gałęski’s concerns about the possibility of the USSR withdrawing their permit for Prof. Zaslavskaya's participation at the last moment and him having to find someone to replace her.

The Congress was well-publicised for that time, when the Internet did not yet exist. Among others, the Call for Paper was published in the body of European Society for Rural Sociology, Sociologia Ruralis journal (1975, Vol. 15, Issue 3) and in Polish rural sociology journals, such as "Village and Agriculture" ("Wieś i Rolnictwo") (3-4/1975, pp. 243-244), as well as “Contemporary Village” (“Wieś Współczesna”) (12/1975, p. 164).

The sessions started on Monday, 9th August 1976, with an opening ceremony in which the guests were welcomed on behalf of the authorities by the Minister of Agriculture at that time and the head of the Honorary Committee, Kazimierz Barcikowski. Vice-president of the Polish Academy of Sciences at 
that time, Professor Jan Szczepański delivered a speech on the Academy's behalf, while G.V. Fuguitt spoke on behalf of IRSA and the European Society for Rural Sociology was represented by its President, Professor Gwyn E. Jones from Great Britain. Participants were greeted by the host of the Congress and the vice-chancellor of the Copernicus University, Prof. Ryszard Bohr and by the secretary of the Torun Voivodeship Committee of the Polish United Workers' Party, Zygmunt Najdowski. Two plenary sessions were held during the Congress. The opening session included programme speeches elaborating upon the main theme of the Congress, delivered by Prof. Alvin Bertrand from Louisiana State University (host of the previous congress) and Prof. Rodolfo Stavenhagen from Mexico (host of the following congress). The $21^{11}$ sekcjach sections also had their own three sessions, each lasting an hour and a half ${ }^{12}$. Their organisers, and at the same time chairmen, represented most of the leading scientific institutions (mainly American) dealing with rural

11 According to the official programme, 22 thematic groups were to conduct sessions, but one of them had to be dismissed due to low frequency attendance and the fact that the chairman has resigned and.

12 A secretary of a Polish sociologist would help the chairman of each thematic group in organising its sessions. In the following list, I have named thematic groups, their chairmen and secretaries (if applicable):

1. Concepts and Strategies for the Integrated Development of Human and Natural Resources: Herbert Koettler (FAO) -

Bogusław Gałęski, IFiS PAN;

2. The Consequences of Economic Growth for Human and Natural Resources Development: Corrado Barberis (Instituto Nazionale di Sociologia Rurale, Italy) - Marek Muszyński (IRWiR PAN);

3. Technological Change in Agriculture and Modernization of Rural Life: The Need for Integrated Development: Prodipto Roy (India) - Jan Turowski (KUL)

4. Demographic Changes and Strategies of Development: Tom Ford (University of Kentucky, USA) - Krzysztof Zagórski

5. Spatial and Regional Planning as Strategies of Development: Horatio Martorelli (Urugwaj) - Zygmunt Pióro

6. Rural Social Change and Land Reforms: Roberto Stavenhagen (Meksyk) - Anna Szemberg, Instytut Ekonomiki Rolnej

7. Collective and Cooperative Farming as a Strategy of Integrated Development: Mihail Cernea (The World Bank, USA) -

Czesław Kos (IRWiR PAN);

8. Employment, Occupational Structure and Strategies of Integrated Development: Tatiana I. Zasławskaja (AN ZSRR) -

Bohdan Jałowiecki; 
and agricultural sociology and decided upon the languages used to deliver speeches and conduct discussions ${ }^{13}$. During the summary session conducted by Prof. Gałęski, reports from thematic group sessions were presented by their leaders. Prof. G.V. Fuguitt officially closed the Congress.

As a part of the programme, 21 science tours around Torun, Bydgoszcz and the Włocławek voivodships were organised. Itineraries were provided by the voivodships' authorities. The tours were organised by the employees of the Faculties of Agriculture and Forestry, by members of the Local Organising Committee and especially by Dr. Lili Maria Szwengrub, with whom I had the chance to take part in all the tours in the spring of 1976. The coaches were provided by a student travel agency, Almatur, among others. The purpose

9. Stratification and Social Mobility of the Rural Population. Implications for Integrated Development: Jose Pastore (Brazylia) - Władysław Adamsk (IFiS PAN);

10. Peasant Societies and the Dilemmas of Development: Joseph Ade Alao (Nigeria) Krzysztof Kwaśniewski (IS UAM);

11. The Future of Rural Communities in Industrialized Societies: Henri Mendras (Universite Paris X, Francja) - Lili Maria Szwengrub, IFiS PAN;

12. The Role of Government in Integrated Development: Bruce Crouch (Australia) Zbigniew A. Żechowski (Wyższa Szkoła Pedagogiczna, Słupsk);

13. Rural Groups and Cooperatives, their Role in Integrated Development: Philip Mbithi (Kenia) - Andrzej Piekara, Spółdzielczy Instytut Badawczy

14. The Changing Roles of Women in Rural Societies: Gelia Castillo (Philippenes) Barbara Tryfan ( IRWiR PAN)

15. Rural Youth - Human Resource or Human Burden?: Bill Kuvlesky (Texas A\&M University, USA) - Barbara Weber (A monthly: „Wieś współczesna”)

16. Minority and Ethnic Groups in the process of Integrated Development: Jerzy Zubrzycki (Australian National University, Australia) - Józef Burszta (UAM)

17. Recration, Leisure and Strategies of Integrated Development: William Buech (Yale University, USA) - Anna Olszewska, (IFiS PAN)

18. The Images of Quality of Life, the Impact of Expectation on Development: Harold Capener (Cornell University, USA) -

Eugenia Jagiełło- Łysiowa (IRWiR PAN)

19. Environmental Development and the Quality of Life: Eugene A. Wilkening (University of Wisconsin, USA) - Zbigniew T. Wierzbicki (IFiS PAN)

20. The Changing Nature of Rural Religious Institutions: Qurinus J. Munters (Agricultural University, Wageningen, Holandia) - Władysław Piwowarski (KUL)

21. The Rural Family Today: Ivan Nye (Washington State University, USA) - Jerzy Piotrowski (IFiS PAN)

13 Five official languages were used during sessions (English, French, Spanish, German and Russian). Interpreters were available only during two plenary sessions. 
of the tours was to meet local artists and to visit places where we were served dinner. As I remember, itineraries were also inspected by Civic Militia and Security Services, although no serious incidents related to these inspections took place. Each coach had a guide speaking in a foreign language, although I am not sure if they were employees of Orbis and Almatur - which were the only tour operators that hired foreign language speakers at that time. They were probably not students. Each thematic group had its own itinerary and tutor as well as a passenger car guiding the coach. The day finished with a group meeting in Ciechocinek at Zdrojowa Café, where we were served refreshments, while listening to live music provided by orchestras from Kowal and Radziejów and the "Pałuki" band from Kcynia. Unfortunately, I do not recall any particular situations related to this evening. Scientific sessions were complemented by many accompanying events.

Among other encounters, a meeting with sociological magazines' publishers from the so-called western and socialist countries was organised. First study groups were forming back then, such as the one created by Bill Kuvlesky of Texas A\&M University - the group for study of the rural youth, to which I belonged.

International meetings were also a great opportunity to promote Poland and its sociological attainments. In the hall of the Copernicus University Library a member of the Local Organising Committee, Włodzimierz Wincławski organised an exhibition of Polish sociological works, which attracted a lot of interest. Polish, German and French scientific books were exhibited and sold on stalls along with local products, such as the famous (and not only in Poland) Torun gingerbread and Włocławek faience. A special post office was opened, where a commemorative postmark of the IV World Congress of Rural Sociology was used.

Dr. Szwengrub's report, already referenced, stated that 704 people took part in the Congress, including guests and accompanying persons. Along with technicians, interpreters, tour guides, receptionists etc. over a thousand ${ }^{14}$ people took part in the event. 491 speeches were submitted and delivered by the academics from all around the world although, as Mikołaj Kozakiewicz

14 L.M. Szwengrub, IV Światowy Kongres Socjologii Wsi.... 
claims, many speakers failed to arrive and most of the speeches were of a diagnostic and analytical nature ${ }^{15}$.

The Congress was also an organisational success, mostly thanks to the commitment on the part of the younger generation of University's employees and students, who spoke foreign languages. Prof. Kwieciński, whom I mentioned before, also emphasises the commitment of the employees of Torun's IRWiR PAN Research Facility, University's administration and students from Young Educators Club.

The scientific meaning of the Congress was summed up by Prof. Gałęski in his statement given to one of the local newspapers: "The Congress was an important stage in the development of rural sociology, a step from a sub-study to a synthesis" ${ }^{\prime 16}$. Broader discussion on the sessions and their scientificmeaning can be found in an interview Prof. Gałęski gave to one of the leading cultural weeklies ${ }^{17}$, where he spoke about the Third World countries dominating the Congress, strong representation of Latin America and Asia and the issues of the USSR's villages being addressed for the first time. The evident return to theory in rural sociology and criticism of the previous developmental strategy, which should be replaced with an integrated development to restore the disturbed ratio between economic growth and the organisation of social life, was considered a novelty by Prof. Gałęski. The concept of the development had to be redefined as, in its previous understanding, it did not take family, neighbourhood and culture into consideration. It was the first instance of such a large-scale presentation of the industrial world in terms of the source of oppression for villages. The rationality of consumption, as an exclusive aim of socio-economic development and a disregard for values it entails, was called in doubt. The topic of peasantry marginalisation was raised, as well as the longing for collective farming, which would be hard to

15 M. Kozakiewicz, IV Światowy Kongres Socjologii Wsi w Toruniu (9-13 VIII 1976 in: "Village and Agriculture" ["Wieś i Rolnictwo"]; 1/1977, pp. 175-179)..

16 News, as of 14-15.08. 1976 as per: L.M. Szwengrub, IV Światowy Kongres Socjologii Wsi, "Rural Sociology Annuals," (“Roczniki Socjologii Wsi”) V. XIV. pp. 264.

17 Return to the Basic Concepts, Jan Bijak’s interview with Prof. Bogusław Gałęski in: "Polityka," 36/1976, 4.09. 1976 pp. 4. 
find among contemporary sociologists. A new social category of part-time farmers came into being.

The proceedings were published in a special publication consisting of fragments of papers printed in both Polish and English, as Volume 61 of Sociological Abstracts/Supplement. Many English-language papers were published to promote the output of Polish rural sociology. In 1976, B. Gałęski became an editor of the English-language paper entitled Rural Sociology in Poland (p.117), which presented a Polish contribution to rural sociology. Other publications included two monographs in English, edited by L. M. Szwengrub and J. Turowski: Rural Social Change in Poland, (Wrocław: Ossolineum, 1976) and Rural Socio-cultural Change in Poland: ed. On the occasion of the Fourth World Congress for Rural Sociology Torun 9-13 August 1976 (Wrocław: Ossolineum, 1977). L. M. Szwengrub was also an editor of a selection of papers entitled The Integrated Development of Human and Natural Resources: The Contribution of Rural Sociology (Wrocław: Ossolineum, 1979). Translations of many speeches given during thematic groups sessions were printed in the following volumes of "Rural Sociology Annuals" ("Roczniki Socjologii Wsi”): V. XIV; V. XV; V. XVI, V. XVII and "Village and Agriculture" ("Wieś i Rolnictwo"): 1/1977; 2/1977; 3/1977. Special issue of "Problems of Agricultural Economics" magazine ("Zagadnienia Ekonomiki Rolnej”) was published in English under the title "Socio-economic Problems of the Development of the Polish agriculture," where selection of works of Polish agricultural economists could be found (supplement to issue no. 2/1976). The magazine was available for purchased during the Congress.

I would like to start the final part of my cogitations with the words of Prof. Gałęski, who I am quoting from my fallible memory: "Greatest scientific discoveries are not made during international congresses, but in the scientists' labs. Congresses are organised for the people to meet and talk". I can only add that many talks and incidents (often humorous) were indeed a part of this event.

I remember how surprised professor Fuguitt and his wife were when I offered them tea in my room at Okęcie Airport Hotel. My task was to pick Mr. And Mrs. Fuguitt up at the airport; they were arriving on a late night flight from Paris. A room at the Airport Hotel was waiting for them. They 
were supposed to spend the next day in Warsaw with Dr. Barbara Weber, an editor from the "Contemporary Village," and then go to Torun afterwards. However, there was some sort of a mechanical breakdown at the hotel and the water was cut off. I had gathered a sufficient supply in my bathtub and a few bottles to drink and to make the said tea. When I brought my guests to my room and offered them tea, Mr. And Mrs. Fuguitt showed no enthusiasm. Only after my comprehensive explanations that I was not going to use the water from my tub, did they accept my offer.

A lengthy queue for sugar outside one of the stores in Torun was filmed by a German cameraman, which was poorly received by the Polish people observing him. The Civic Militia came to check the cameraman's identity, but unfortunately I cannot remember how this event concluded.

I intend to devote this special paragraph to culinary issues which arose during this event. The Congress was taking place in times of a shortage, and so the issue of food supplies for its participants received a lot of attention. The organisers were concerned about providing an appropriate menu that could be appreciated by all the guests. Two parties for the participants were planned as a part of the event. The first one was a cocktail party, which took place early afternoon in the library after the opening plenary session. Sandwiches, wine and other drinks were served at that party. It was very elegant for such poor times and it made a fine impression on the participants. There was not much space and people were crowding into the room, but it was the only issue that I recall. Lunch was served in a new canteen and I think that this time, participants had to pay for what they ate.

The problem remained of a formal supper that was supposed to finish the Congress. Having attended many international conferences, Professor Gałęski claimed that there should be a formal dinner at the table. He anticipated toasts, votes of thanks and speeches from both the representatives of the International Society and the Polish participants. He considered it inappropriate to give such speeches to people who stood while eating. The problem was that the university campus did not have many spaces capable of housing 600 people. The only option was the canteen, which was used as a banquet hall.

I still remember the image of a huge canteen with multiple tables stacked with brown striped faience plates, so typical of school and workers' canteens. On each plate, there was a small piece of smoked eel which, surprisingly, matched the plates. I do know that we were drinking white wine, but for some 
reason, I can't remember the main course. Maybe the eel was the only food there was. However, I do remember participants' surprise when they saw the plates and the embarrassing atmosphere that came afterwards. I did not know the people responsible for the menu, but it perfectly reflected the Polish idea of luxury associated with high prices. Smoked eel was, as it is today, expensive and hard to come by. Prof. Gałęski was openly dissatisfied, but the speeches were made and glasses were eventually raised. The Congress could officially finish.

While certain participants returned home, many people, especially the young ones, wanted to extend their stay in Poland and visit its most important places, using contacts they made during the Congress. I remember being woken up by a doorwoman in a doctoral students' hotel, where I lived at that time. In the lobby, I met a group of ten Frenchmen, members of the Congress, who had come to Warsaw by van and wanted to do some sightseeing before they left. They couldn't count on finding a place to stay, not only because of the high costs of such services, but also because Polish hotels lacked rooms. A mutual friend gave them my address and told them they could spend the night on my floor. Fortunately, the hotel had a large guestroom with 8 free beds, where the unexpected guests could be accommodated. It wasn't very expensive; the only thing they had to pay for was the sheets, so they ended up feeling very happy and the next morning we ate breakfast together.

\section{References}

Kozakiewicz, M., 1977. IV Światowy Kongres Socjologii Wsi w Toruniu (13 VIII 1976) [World Rural Sociology Congress in Torun (9-13 VIII 1976)]. In: Wieś i Rolnictwo [Village and Agriculture], 1/1977.

News, as of 14-15.08. 1976. As per: Szwengrub L.M., 1976. IV Światowy Kongres Socjologii Wsi in Toruń, 9-13.VIII 1976 [World Rural Sociology Congress in Torun (9-13 VIII 1976)]. In: Roczniki Socjologii Wsi [Rural Sociology Annuals], $\mathrm{XIV} / 1976$.

Return to the Basic Concepts, Jan Bijak's interview with Prof. Bogusław Gałęski in: Polityka. 36/1976, 4.09. 1976.

Szwengrub L.M., 1976. IV Światowy Kongres Socjologii Wsi in Toruń, 9-13.VIII 1976 [World Rural Sociology Congress in Torun (9-13 VIII 1976)]. In: Roczniki Socjologii Wsi [Rural Sociology Annuals], XIV/1976. 